\title{
Invensi Dalam Genre Detektif
}

\author{
Viona Rizky Handayani ${ }^{1 *)}$, Diana Puspitasari ${ }^{2)}$, Hartati $^{3)}$ \\ PS Sastra Jepang, FIB, Universitas Jenderal Soedirman \\ Purwokerto,Jawa Tengah \\ ${ }^{1}$ [vionarizkyhan@ gmail.com], ${ }^{2}$ [dianapuspitasari@unsoed.ac.id], ${ }^{3}$ hartati.unsoed.ac.id]
}

\begin{abstract}
Abstrak
Penelitian ini bertujuan untuk mendeskripsikan formula detektif dalam anime Jepang tahun 2014-2016 yang diantaranya adalah Meitantei Konan I Jigen no, Ryuugajou Nanana No Maizoukin, Sniper Psycho-Pass : The Movie( Gekijou-ban Psycho-Pass ), Ghost In The Shell, Meitantei Konan Junkoku no Naitomea, dan Bungou Stray Dogs Season 1. Metode yang digunakan ialah metode deskriptif kualitatif dengan pendekatan formula sastra dari Cawelti. Hasil penelitian ini menunjukkan konvensi formula detektif pola tindakan yang terdiri dari enam fase dan empat peran, yaitu 1) pengenalan detektif, 2) kejahatan dan petunjuk, 3) penyelidikan, 4) pengumuman solusi, 5) penjelasan solusi dan 6) akhir cerita. Selanjutnya, untuk empat peran tersebut diantaranya adalah 1) korban, 2) penjahat, 3) detektif dan 4) mereka yang terancam oleh kejahatan namun tidak mampu menyelesaikan. Selanjutnya, ditemukan akhir cerita yang merupakan invensi arketipe pada anime Ryuugajou Nanana No Maizoukin, sedangkan untuk kelima anime lainnya memiliki konvensi arketipe sesuai dengan teori Cawelti. Selain itu, pada penelitian ini ditemukan adanya invensi formula yang terjadi pada setiap anime detektif. Bentuk invensi yang terjadi pada anime detektif adalah adanya penambahan formula supernatural dalam jalan ceritanya Berdasarkan hasil analisis data, disimpulkan bahwa keenam anime memiliki konvensi formula genre detektif dan invensi formula di dalamnya. Konvensi dan invensi pada formula terjadi seiring dengan perkembangan minat penonton pada genre tersebut. Semakin populer suatu genre tertentu maka akan selalu ada bentuk konvensi dan invensi sebagai pengembangan dari bentuk formula dan arketipe.
\end{abstract}

Kata kunci : Anime, Formula, Pola Tindakan, Genre Detektif.

\begin{abstract}
The purpose of this research to describe the detective formulas in Japanese anime 20142016, Meitantei Konan I Jigen no, Ryuugajou Nanana No Maizoukin, Sniper Psycho-Pass: The Movie ( Gekijou-ban Psycho-Pass ), Ghost In The Shell, Meitantei Konan Junkoku no Naitomea, and Bungou Stray Dogs Season 1. The method used was descriptive qualitative with literary formula approach based on Cawelti. The results of this study show that detective action pattern conventions consisting of six phases and four roles. That are 1) introduction of detectives, 2) crime and guidance, 3) investigation, 4) announcement of solution, 5) solution explanation, 6) end of story. In addition, these four roles are those who are exposed to the threat of 1) victims, 2) criminals, 3) detectives, and 4) crimes, but cannot resolve them. Then, it was found that the ending of the story was an archetypal invention in the anime Ryuugajou Nanana No Maizoukin, while the other five anime had archetypal conventions according to Cawelti's theory. In addition, in this study, it was found that there is a formula invention that occurs in every detective anime. The form of invention in detective anime is to add a supernatural formula to the storyline. Based on the results of data analysis, it can be concluded that the six animes contain the rules and inventions of the formula detective genre. Formula conventions and inventions occur as the audience becomes more interested in the genre. The more popular a particular genre, the more conventions and inventions as a development of formulas and archetypes.
\end{abstract}

Keywords : Anime, Formula, Action pattern, Detective Genre. 


\section{Pendahuluan}

Sastra populer secara umum adalah karya sastra atau seni yang diterima oleh masyarakat banyak, dikonsumsi oleh masyarakat melalui jumlah penjualan yang meningkat (Ida, 2011:24). Salah satu bentuk karya sastra populer yang diterima dan dikonsumsi masyarakat adalah film animasi atau anime. Anime masuk ke dalam bentuk dari fiksi populer karena anime merupakan salah satu karya sastra populer yang banyak dikonsumsi oleh masyarakat dengan berbagai macam alasan, salah satunya karena genre yang menarik. Secara teoritis menurut Cawelti (1976: 6) bahwa suatu produk sukses karena formulanya dan formulaic suatu genre itu sama, tidak terlalu jauh inovasinya, maka dari itu dapat dikatakan bahwa genre tersebut banyak diminati karena formula serta formulaiknya sama. Dari penjelasan tersebut dapat dilihat bahwa sebuah karya sastra akan menjadi populer jika ada formulanya, sedangkan formula nantinya akan membentuk genre, genre sebagai penentu dari penonton atau pembaca dalam menjadikan karya sastra tersebut dianggap populer.

Genre berasal dari bahasa Prancis yang diartikan sebagai jenis atau kelas. Istilah genre dipakai dalam dunia sastra sejak zaman dulu karena dijadikan sebagai penentuan tipe atau jenis karya sastra (Ida 2011:195). Genre juga memiliki banyak jenisnya, seperti yang dijelaskan pada catatan Daniel Lopez dalam bukunya yang berjudul Film by Genre (1993), ada lebih dari 300 genre dan terdapat 775 kategori, tren, gaya, dan gerakan dalam genre film. Genre detektif dianggap populer karena masyarakat banyak yang menyukai genre ini. Seperti yang dijelaskan bahwa penentuan genre fiksi populer tergantung dari penonton dan penonton lah yang menjadi indikator dapat tidaknya fiksi tersebut terjual. Dikatakan bahwa western, komedi, dan musk adalah film genre mapan karena mudah dikenali; dan roman, serta detektif, adalah genre mapan karena alasan yang sama. Dengan kata lain, produk-produk tersebut telah memenuhi minat penonton untuk beberapa waktu yang lama (Ida, $2011: 201)$.

Genre tersusun dari formula dan arketipe yang keduanya itu berbeda. Jika formula didefinisikan sebagai kombinasi konvensi budaya yang spesifik antara satu budaya dengan budaya lainnya, sedangkan untuk arketipe merupakan pola cerita yang tidak dibatasi oleh kebudayaan tertentu maupun oleh waktu. Arketipe dalam cerita genre detektif yaitu ketika seseorang mendengar kata detektif maka muncul pola cerita yaitu suatu penyelidikan terhadap suatu kejahatan dan bagaimana sulitnya pemecahan masalah yang dilakukan oleh tokoh detektifnya. (Ida, 2011: 208-211). 
Penelitian genre diartikan sebagai meneliti konvensi dan invensi suatu genre dalam rangka untuk melihat perkembangan suatu genre yang diteliti. Kemudian, penelitian genre menyangkut kepada penelitian formula, arketipe dan ikon fiksi populer (Ida, 2011:204-206). Oleh karena itu, penelitian genre detektif ini dilatarbelakangi oleh adanya konvensi dalam sebuah genre yang menunjukkan bahwa genre detektif pada anime Jepang tahun 2014-2016 masih tetap berpegang pada konvensi detektif yang mapan. Sebuah penelitian tentang genre karya sastra yang populer dilakukan dengan melihat elemen penting atau unsur dari suatu karya sastra yang disebut sebagai formula. Penulis mengambil 6 anime sebagai objek penelitian, dengan berbagai judul diantaranya adalah Meitantei Konan I Jigen no, Ryuugajou Nanana No Maizoukin, Sniper PsychoPass: The Movie (Gekijouban Psycho-Pass), Ghost In The Shell, Meitantei Konan Junkoku no Naitomea, dan Bungou Stray Dogs Season 1.

Formula merupakan elemen penting dalam terbentuknya sebuah genre, dan genre yang akan dibahas di sini adalah genre detektif. Formula berdampingan dengan arketipe dari genre detektif. Genre detektif bermula dari genre misteri, yang pada akhirnya dapat berdiri sendiri karena genre ini memiliki ciri khas tersendiri. Menggunakan kajian genre dari John G Cawelti dengan melihat struktur narasi genre detektif sebagai sistem keseluruhan formula pada anime dalam rentang tahun 2014 sampai 2016, kemudian menganalisis arketipenya. Oleh karena itu, berdasarkan rumusan masalah yang ada, maka permasalahan yang dapat dijadikan sebagai pertanyaan penelitian adalah sebagai berikut:

1. Bagaimanakah formula yang ada pada genre detektif anime Jepang tahun 2014 $-2016 ?$

2. Bagaimanakah arketipe yang ada dalam genre detektif anime Jepang tahun 2014-2016?

\section{Metode dan Teori}

\subsection{Metode Penelitian}

Jenis penelitian menunjukkan pendekatan dan metode yang digunakan penulis dalam merencanakan sebuah kegiatan penelitian. Penulis menggunakan jenis metode penelitian deskriptif kualitatif. Penelitian kualitatif ditunjukkan untuk memahami fenomenafenomena sosial dari sudut pandang partisipan. Oleh karena itu, pengertian dari penelitian kualitatif adalah penelitian yang digunakan untuk meneliti pada kondisi subjek alamiah dimana peneliti merupakan kunci instrumen. (Sugiyono, 2005:14) Metode pengumpulan 
data yang digunakan dalam penelitian ini adalah menggunakan teknik simak dan teknik catat. Teknik simak adalah penyediaan data yang diperoleh melalui menyimak data penggunaan bahasa yang diantaranya yaitu bahasa lisan. (Sudaryanto, 1993:133) Selanjutnya, ketika menerapkan teknik simak maka dilanjutkan dengan teknik lanjutan yaitu teknik catat, teknik catat adalah metode yang dilakukan ketika menerapkan metode simak dan berlanjut menjadi teknik simak catat. (Mahsun, 2005: 93-94)

\subsection{Teori}

Menurut Cawelti (1976:81-82), formula genre detektif berpusat pada penyelidikan si detektif dan solusi dari kejahatan tersebut. Terdapat enam fase utama dalam pola ini, yaitu pengenalan detektif, kejahatan dan petunjuk, penyelidikan, pengumuman solusi, penjelasan solusi dan akhir cerita. Kemudian, terdapat empat peran diantaranya adalah korban, penjahat, detektif dan mereka yang terancam oleh kejahatan namun tidak mampu menyelesaikan. Selain itu ada juga formulaik yang berisi tentang hal-hal yang berkaitan dengan detektif, diantaranya topi, kaca pembesar, buku dan lain sebagainya. Pada penentuan genre, peneliti melihat kesamaan dari berbagai cerita sejenis dan menentukan formula yang menunjukkan kesamaan dan perbedaan sehingga dapat dilihat jenis atau genrenya. Apabila pengulangan suatu jenis fiksi dengan ciri-cirinya yang berlangsung secara konsisten dan kemudian dikenali pembaca atau penonton maka fiksi dengan ciriciri tersebut dapat dikategorikan menjadi penentu genre tersebut (Ida, 2011: 203 ).

\section{Hasil dan Pembahasan}

Ghost In The Shell dirilis pada tahun 2015 dengan rating 9/10. Selanjutnya akan disingkat menjadi GIT. Pada 8 Januari 2015, sebuah trailer teaser pendek mencantumkan Kazuya Nomura sebagai sutradara, Kazuchika Kise sebagai desainer karakter, Toru Okubo sebagai sutradara animasi, Tow Ubukata sebagai penulis skenario, dan Cornelius sebagai komposer. Film ini diumumkan dengan rilis tentatif 'awal musim panas 2015' di bioskop Jepang. Berikut merupakan enam fase dalam anime Ghost in The Shell:

\subsection{Pengenalan Detektif}

Pada pengenalan detektif yang ada di anime Ghost In The Shell, dijelaskan melalui kepintaran seorang perempuan bernama Motoko dalam memecahkan teka-teki, ia adalah mayor dari unit independen ofensif, unit atau section yang dikenal sebagai detektif. 
Adanya kepintaran dan kecerdasan dari Motoko serta Motoko yang dipercaya untuk menyelidiki kasus kejahatan yang terjadi, merupakan pengenalan detektif untuk membuktikan bahwa Motoko adalah detektif yang pintar dan tidak pernah takut akan bahaya atau tantangan.

Data 79: Gambar 79.

Motoko sedang merundingkan sebuah rencana
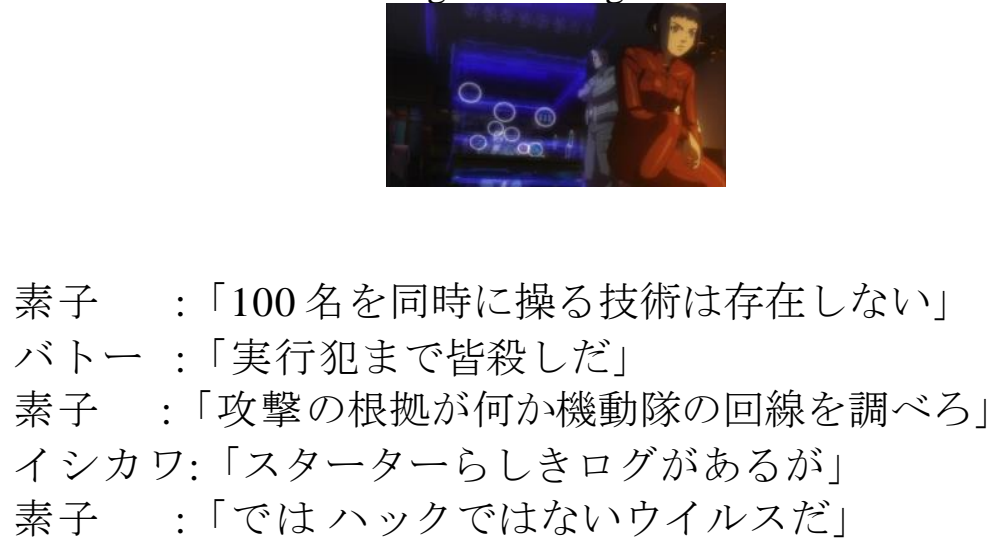

Motoko : Hyaku-mei o dōjini ayatsuru gijutsu wa sonzaishinai.

Batou : Jikkō-han made minagoroshida.

Ishikawa : Sutātārashiki rogu ga aru ga.

Motoko :De wa hakkude wanai uirusuda.

Motoko : 'Tak ada teknologi yang dapat mengendalikan 100 orang sekaligus.'

Batou : 'Para penjahat yang aku lihat semuanya mati.'

Ishikawa : 'Periksa jalur regu anti huru-hara dan cari taulah apa penyebab serangan itu terjadi.'

Motoko : 'Ini bukan peretasan, tapi ini adalah virus.'

(GIT, 00:06:47 - 00:06:59)

Motoko yang merupakan seorang detektif tengah berunding bersama Batou dan Ishikawa yang mana mereka adalah kelompok dari detektif yang sedang menyelidiki tentang kekacauan yang terjadi dengan spekulasi adanya teroris yang menyebarkan virus berbahaya kepada orang-orang. Motoko adalah detektif, dilihat dari Motoko yang pintar dan cerdas dalam menemukan kejahatan apa yang sebenarnya terjadi, dan Batou yang meminta Motoko untuk menyelidiki penyebab dari serangan itu.

\subsection{Kejahatan dan Petunjuk}

Kejahatan memiliki definisi yang biasanya secara langsung mengikuti setelah adanya penjelasan tentang si detektif. Kejahatan yang terjadi di anime Ghost In The Shell adalah tentang adanya virus cyber yang berbahaya dan diikuti oleh petunjuk yang 
mengarah pada tersangka.

\section{Data 80:}

Gambar 80

Pembicaraan Hozumi dengan Aramaki tentang virus cyber
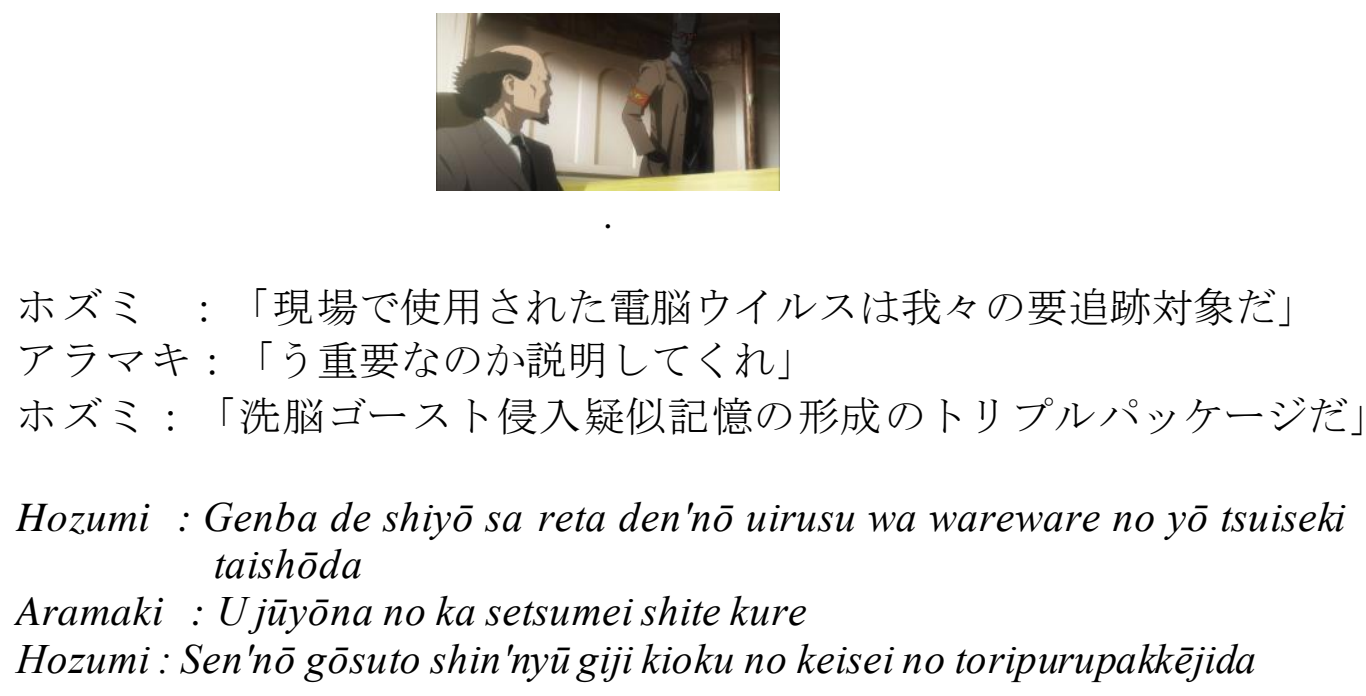

Hozumi : 'Virus cyber yang digunakan sangat penting untuk penyelidikan kami.' Aramaki : 'Kenapa penting?'

Hozumi : 'Adanya pencucian otak, penyusupan ghost dan penciptaan ingatan palsu, menjadi tiga rangkap.'

(GIT, 00:13:28-00:13:41)

Dialog di atas menunjukkan adanya kejahatan yang terjadi berupa virus cyber dari teroris yang menyebabkan tiga rangkap kejahatan yaitu pencucian otak, penyusupan ghost dan penciptaan ingatan palsu. Namun dalam percakapan Hozumi dan Aramaki tersebut dapat menjadi sebuah petunjuk tentang siapa penjahat yang sebenarnyaa dilihat dari Hozumi yang membutuhkan virus cyber itu, padahal virus itu sangat berbahaya.

\subsection{Penyelidikan}

Penyelidikan diikuti oleh parade dari tersangka, yaitu Emma. Emma dibawa oleh detektif ke tempat yang dipercaya dapat menyelidiki siapa sosok Emma sebenarnya. Tsugumi yang merupakan robot, digunakan untuk menyelidiki apa yang Emma miliki di dalam tubuh dan otaknya. 
Data 81:

Gambar 81.

Dilakukan penyelidikan tentang Emma si tersangka

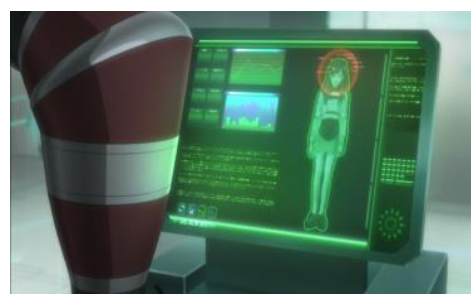

ツムギ 2 : 「彼女はクルツ中佐付きの電子戦技官だ」

ツムギ 2 ：「彼女は特殊なニューロチップ型電脳を持つハッカーを探 索していた」

ツムギ 1:「通称スケアクロウ」

ツムギ 1 : 「ハリマダラ社を襲ったサイバーテロの容疑者だ」

Tsumigi 2 : Kanojo wa kurutsu chūsa-tsuki no denshi-sen gikanda

Tsumigi 2 : Kanojo wa tokushuna nyūrochippu-gata den'nō o motsu hakkāo tansaku shite ita.

Tsumugi $1:$ Tsūshō sukeakurō.

Tsumugi 1 : Harimadara-sha o osotta saibātero no yōgi-shada.

Tsumugi 2 : 'Dia dalah seorang teknisi dalam komando Letkol. Kurz.'

Tsumugi 2 : 'Dia menyelidiki peretas Neurochip tipe cyberbrain khusus.'

Tsumugi 1 : 'Disebut Scarecow.'

Tsumugil : 'Dia seorang tersangka dalam serangan teroris di Harimadara'

(GIT, 00:27:15 - 00:27:29)

Diperlihatkan dialog dari Tsumugi 1 dan Tsumugi 2 yang menjelaskan tentang siapa Emma sebenarnya. Mereka melakukan penyelidikan agar mengetahui kebenaran tentang Emma yang merupakan seorang teroris atau hanya sebagai pihak yang dijadikan tameng untuk penjahat yang sesungguhnya. Pada menit 00:27:15-00:27:29 merupakan salah satu hasil dari penyelidikan yang detektif lakukan. Tsugumi adalah robot, alat yang digunakan untuk menyelidiki apa yang Emma ( tersangka ) miliki di dalam tubuh dan otaknya.

\subsection{Pengumuman Solusi}

Sejak awal anggota kepolisian memang tidak banyak terlibat dalam anime Ghost In The Shell. Aksi dalam cerita detektif fokus pada penyelidikan misteri kejahatan, dan adanya pengumuman yang tenang dari si Motoko sebagai Detektif bahwa dia telah sampai pada sebuah solusi untuk penangkapan penjahat. 


\section{Data 82: $\quad$ Gambar 82}

Para detektif menemukan solusi untuk penangkapan penjahat.
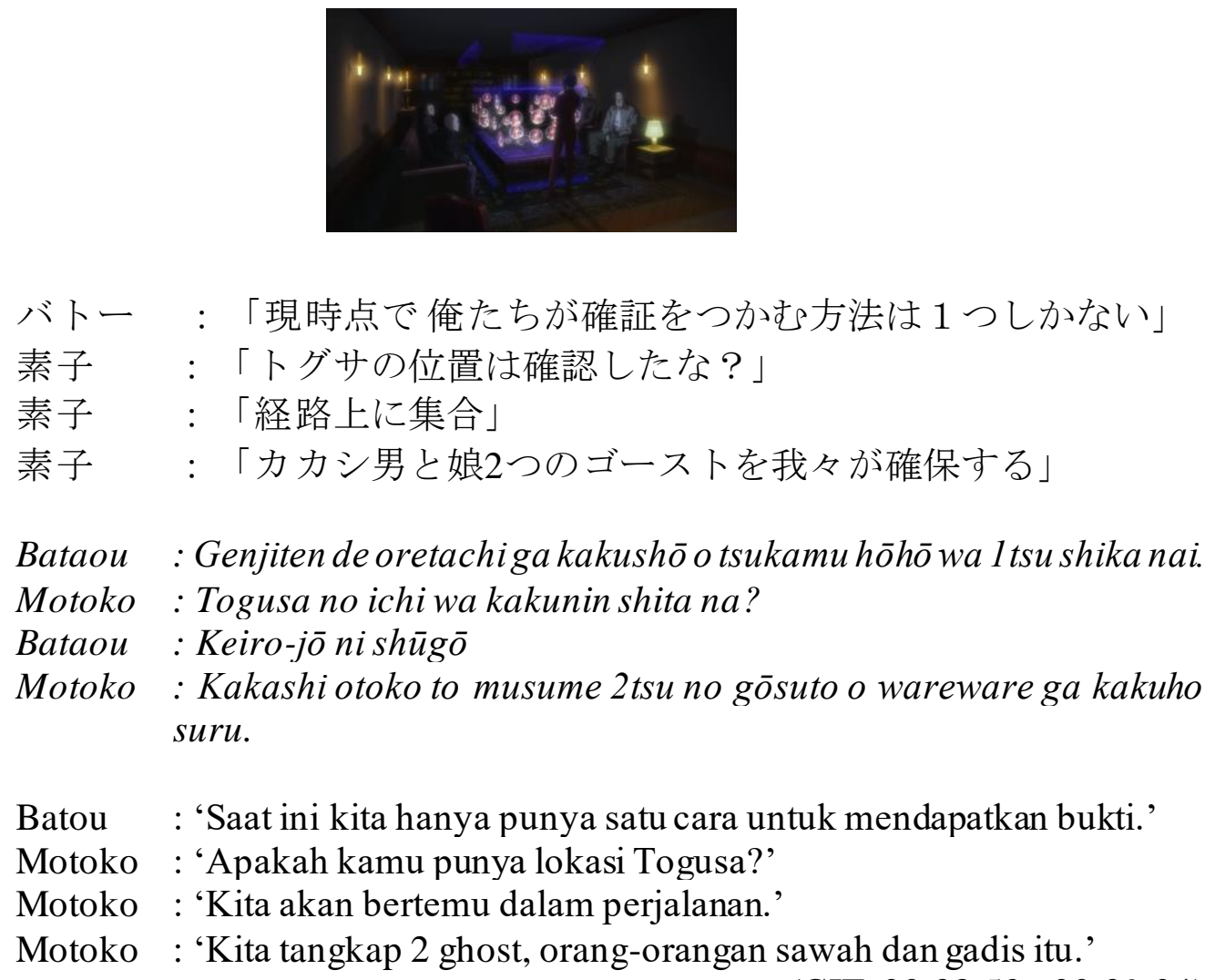

Dialog di atas menunjukan bahwa Motoko sebagai detektif bersama temantemannya sudah memiliki cara untuk menangkap si penjahat teroris, dengan cara mereka harus menangkap semua tersangka. Hal ini juga menunjukkan bahwa detektif lebih baik dalam menangani sebuah masalah dan mampu memecahkan masalah dengan ide yang pintar, tidak seperti polisi yang selalu gagal memecahkan suatu permasalahan.

\subsection{Penjelasan Solusi}

Motoko sebagai detektif menjelaskan alasan atau asumsi yang menggiringnya kepada solusi dan mengungkapkan bagaimana dan mengapa tindak kejahatan itu dilakukan. 


\section{Data 83:}

Gambar 83

Penjelasan solusi dari Motoko.
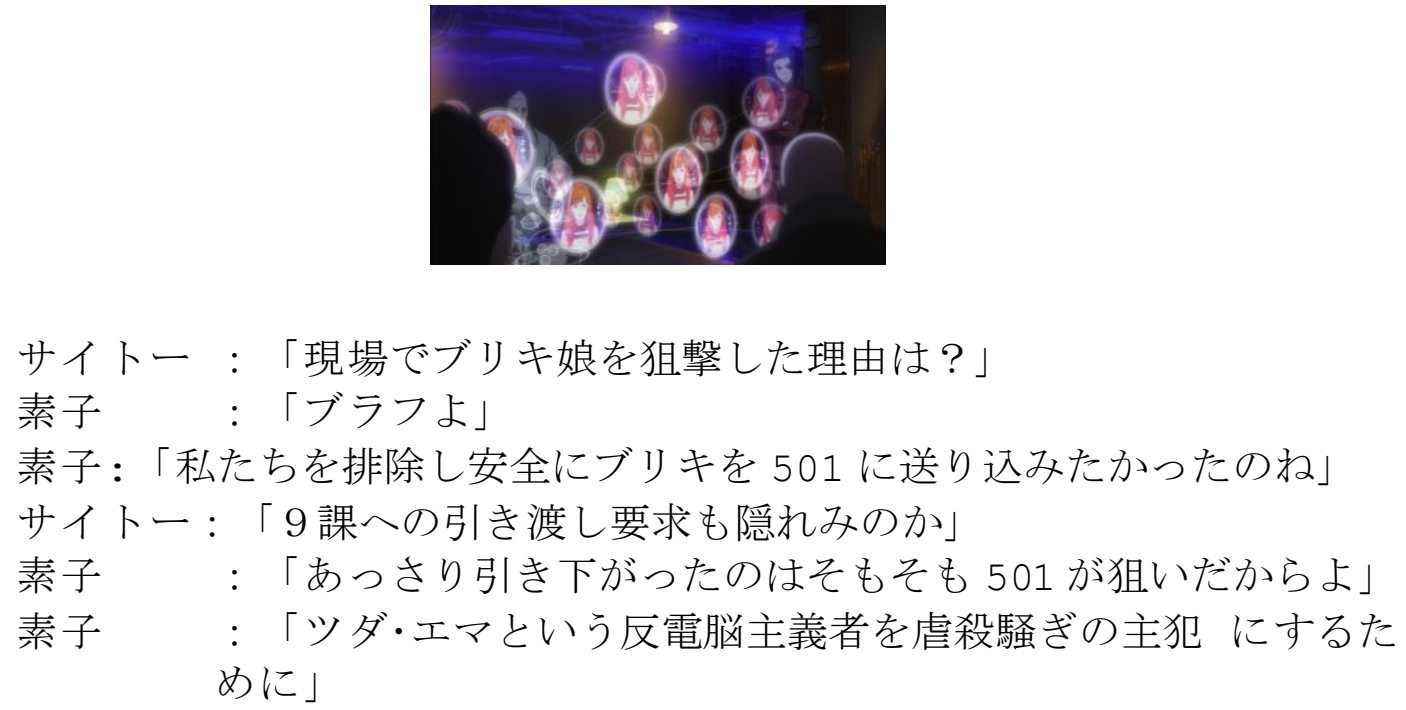

Saitou : Genba de buriki musume o sogeki shita riyū wa?

Motoko : Burafuyo.

Motoko : Watashitachi wo haijo shi anzen ni buriki wo 501 ni okurikomitakatta no ne.

Saitou : Kyu-ka e no hikiwatashi yōkyū mo kakuremino ka.

Motoko : Assari hikisagatta no wa somosomo 501 ga neraidakarayo.

Motoko : Tsuda Ema to iu han den'nō shugi-sha o gyakusatsu sawagi no shuhan ni suru tame ni.

Saitou : 'Lalu kenapa gadis itu ditembak?'

Motoko : 'Hanya gertakan.'

Motoko : 'Dipastikan dia ingin menyingkirkan kita dan mengamankan Gadis Timah ke 501.'

Saitou : 'Jadi kunjungan dia ke sektro 9 hanya tabir saja?'

Motoko : 'Dia mundur dengan begitu mudahkarena mengincar unit501 dari awal.'

Motoko : 'Sehingga ia bisa mengatur anti-cyberbrain Emma Tsuda untuk memimpin pembantaian itu.'

(GIT, 00:38:01 - 00:38:21)

Data di atas memperlihatkan adanya asumsi atau opini yang Motoko katakana tentang alasan kejahatan dilakukan oleh pelaku. Sejak awal kejahatan terjadi karena ingin menghancurkan Motoko dan Unit 501. Sehingga, Emma dijadikan sebagai umpan agar mereka salah menangkap penjahat. 


\section{Data 84:}

Gambar 84

Batou meminta kerjasama kepada semua detektif


バトウ：「感染で疑似記憶を植え付けられるのは確かだな？」
バトウ：「共有フォームがあるはずだ」

Batou : Kansen de giji kioku o uetsuke rareruno wa tashikada na?

Batou : Kyōyū fōmu ga aru hazuda.

Batou : 'Kita tahu pasti infeksi ini tertanam ingatan palsu, bukan?'

Batou : 'Kita harus kerjasama'

(GIT, 00:39:11 - 00:39:18)

Pada penggalan dialog menit 00:39:11-00:39:18 yang Batou ucapkan, ia meminta untuk saling bekerjasama kepada semua detektif yang turun ke lapangan, dan mereka pergi ke lokasi dimana mereka akan menemukan tersangka kejahatan. Detektif akan menangkap para tersangka namun mereka akan tetap saling bekerja sama karena virus cyber itu sangat berbahaya. Sebuah penjelasan bahwa kejahatan itu adalah 'infeksi yang tertanam ingatan palsu' menyatakan bahwa yang dikatakan Batou adalah asumsi yang menggiring pada solusi untuk bekerja sama.

\subsection{Akhir Cerita}

Akhir cerita merupakan akhir dimana penjahat tertangkap dan mengakui kesalahannya. Kolonel Hozumi diperiksa setelah adanya penembakan di lokasi pengejaran tersangka, kemudian Hozumi mengakui kesalahannya dengan barang bukti yang telah ditemukan.

Data 85:

Gambar 85

Emma tewas tertembak.

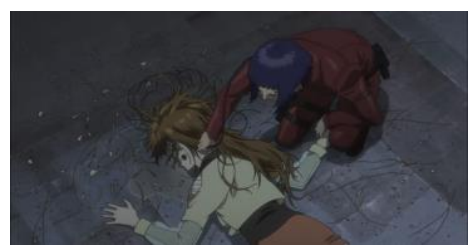

(GIT, 00:41:12) 
Data di atas memperlihatkan gambaran dimanaEmma tewas karena ditembak. Emma yang ditetapkan juga sebagai tersangka pada akhirnya tewas atau rusak. Motoko memasangkan kabel ke belakang leher Emma untuk memeriska apa yang ada ditubuh dan pikiran Emma.

\section{Data 86:}

Gambar 86

Motoko ditahan di dalam penjara.
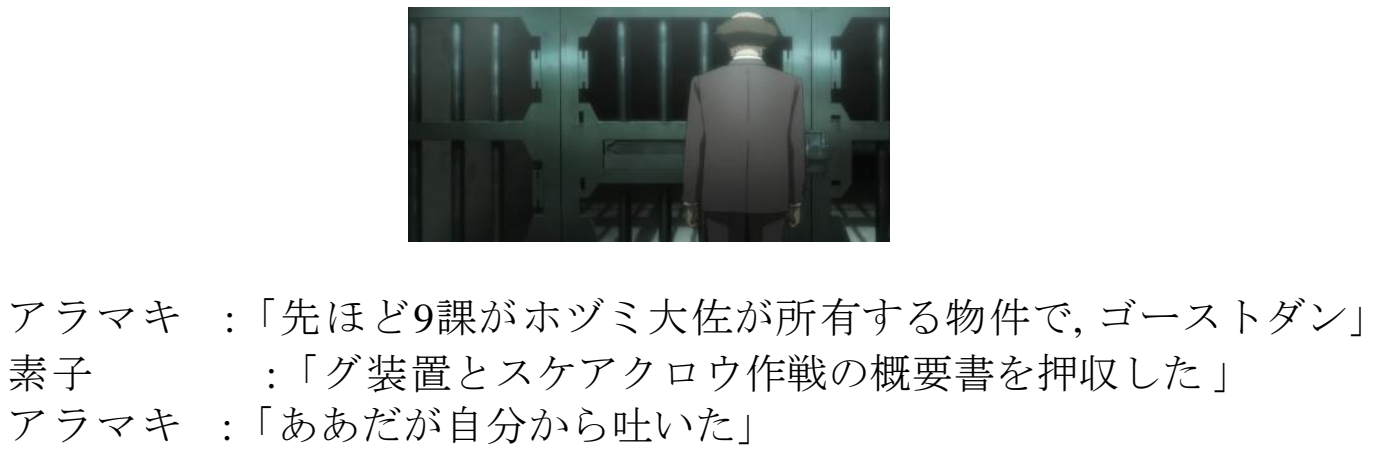

Aramaki : Saki hodo kyuuka ga hodzumi taisa ga shoyū suru bukken de ichi, gōsutodabingu sōchi to ichi sukeakurō sakusen no gaiyō-sho o ōshū shita.

Motoko : Demo taiho wa dekinakatta.

Aramaki : A dagajibun karahaita

Aramaki : 'Sektor 9 memeriksa barang kolonel Hozumi, dan menyita perangkat dab ghost serta scarecrow.'

Motoko : 'Tapi mereka tak bisa menangkapnya.'

Aramaki : :'Ya, dia mengakuinya.'

(GIT, 00:48:59 - 00:49:11)

Akhir cerita ditutup dimenit ke 00:48:59-00:49:11. Pada awalnya, Motokoditahan karena menjadi tersangka kerusuhan, namun kemudian Kolonel Hozumi yang diperiksa setelah adanya penembakan di lokasi pengejaran tersangka, mengakui kesalahannya dengan barang bukti yang telah ditemukan. Hozumi mengaku bahwa ia ikut dalam penyebaran virus cyber. Pengakuan dari penjahat adalah akhir dari sebuah solusi dan terpecahkannya misteri kejahatan yang ditangani oleh detektif.

Selanjutnya, dalam cerita detektif klasik terdapat empat peran utama yang melengkapi formula pola tindakan dalam genre detektif yaitu:

\subsection{Korban}

Pada penjelasan berkaitan tentang korban, penonton tidak diberikan informasi yang terlalu banyak tentang identitas pribadi korban karena fokus terhadap penyelidikan penangkapan penjahat. Jika ada efek emosional tentang kroban maka akan bergeser ke 
tragedi dan kesedihan, mengacaukan formula dari cerita.

\section{Data 87:}

Gambar 87

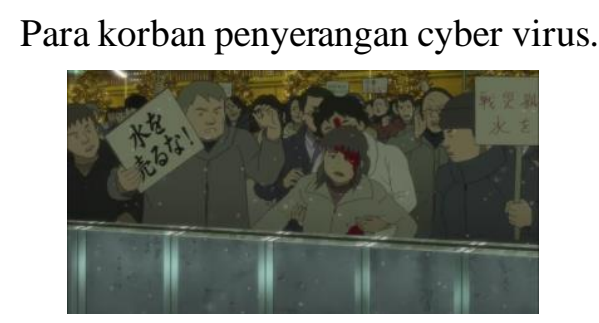

Beberapa orang yang menjadi korban dalam penyerangan cyber virus, namun biodatanya tidak akan diperlihatkan secara jelas jika bukan termasuk tokoh-tokoh yang berkepentingan, namun ada korban khusus yaitu salah seorang gadis bernama emma, ia menjadi perantara virus tersebut karena ia sudah berjanji pada ghost dalam dirinya yang merupakan ayahnya.

\subsection{Penjahat}

Penjahat bisa disebut sebagai tokoh yang harus ada di dalam cerita detektif. Para penjahat memiliki motif yang kompleks, aksi-aksi yang menarik, namun tetap selalu dapat didefinisikan suatu keburukan. Pada anime Ghost In The Shell Season I untuk para penjahat disebut sebagai teroris yang menyebarkan cyber virus.

\section{Data 88:}

\section{Gambar 88}

Penjahat yang menyamar sebagai pihak keamanan dan mengarahkan pistolnya untuk menembak masyarakat tak bersalah.

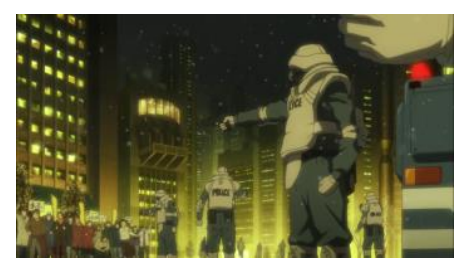

\subsection{Detektif}

Detektif sebagai protagonis utama atau detektif, peran detektif sangatpenting dan sangat ditekankan pada cerita detektif. Anime Ghost In The Shell Season I memiliki detektif Mayor Motoko dan Aramaki dari kepolisian yang kemudian membentuk regu serbu yang lebih dikenal sebagai Section 9 atau unit independen of ensif bersama teman- 
temannya yang lain.

Data 89:

Gambar 89

Tokoh Motoko si detektif hebat.

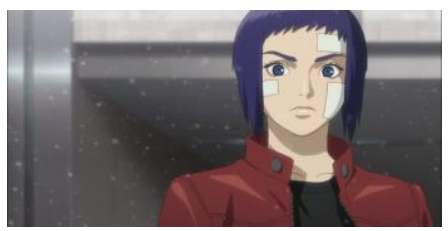

Pada data ke-90 menunjukkan seorang perempuan yang berperan sebagai tokoh detektif di anime Ghost In The Shell Season I, perempuan tersebut bernama Mayor Matoko.

\subsection{Mereka Yang Terancam Oleh Penjahat Tapi Tidak Dapat Menyelesaikan}

Pemeran pendukung yang hadir di sebuah cerita detektif, mengalami kerugian atas kejahatan yang dilakukan penjahat.

\section{Data 90:}

Gambar 90

Korban yang berjatuhan adalah orang-orang yang tak dapat menyelesaikan masalah

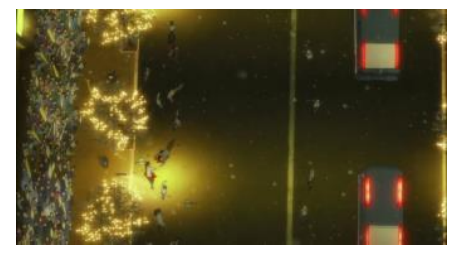

(GIT, 00:06:13)

Pada anime Ghost In The Shell menit ke 00:06:13 diperlihatkan dengan adanya korban yang berjatuhan adalah demonstran yang sedang demo di depan gedung wakil menteri. Mereka adalah orang yang tidak dapat menyelesaikan masalah, mereka seperti korban yang tidak beruntung dalam kasus yang ada atau masalah yang ada.

\section{Simpulan}

Berdasarkan hasil pembahasan mengenai formula genre detektif pada anime Jepang pada kurun waktu tahun 2014-2016 ditemukan bahwa formula dan arketipe merupakan unsur yang melengkapi elemen pada genre khususnya genre detektif dalam penelitian ini. Pada genre detektif terdapat formuladalam bentuk pola tindakan enamfase dan empat peran yang diantaranya adalah, pengenalan detektif, kejahatan dan petunjuk, penyelidikan, pengumuman solusi, penjelasan solusi, dan akhir cerita yang diikuti dengan 
korban, detektif, penjahat dan orang yang terancam namun tidak dapat menyelesaikan masalah. Sedangkan untuk arketipe atau pola cerita umumnya yang muncul dari genre detektif ini adalah penyelidikan terhadap suatu kejahatan dan bagaimana pemecahan yang dilakukan oleh tokoh detektifnya.

Pada analisis yang dilakukan terhadap enam anime genre detektif tampak adanya konvensi, persamaan, dan invensi dalam formula yang terjadi pada setiap anime. Bentuk invensi yang terjadi pada anime detektif adalah adanya penambahan formula supernatural dalam jalan ceritanya. Hal tersebut tampak dalam anime Ryuugajou Nanana No Maizoukin, Sniper Psycho-Pass : The Movie ( Gekijouban Psycho-Pass), Ghost In The Shell, dan Bungou Stray Dogs Season 1 yang mengembangkan bentuk formula dalam barang yang digunakan oleh detektif dalam melancarkan aksi penangkapan penjahat. Dalam anime tersebut menggunakan kekuatan supernatural, pistol tanpa peluru dan tidak lagi membutuhkan buku catatan serta kaca pembesar.

Kemudian, ditemukannya pengembangan genre detektif melalui arketipe yang ditemukan pada anime Meitantei Konan I Jigen no, Sniper Psycho-Pass: The Movie (Gekijouban Psycho-Pass), Ghost In The Shell, Meitantei Konan Junkokuno Naitomea, dan Bungou Stray Dogs Season 1 yang memiliki fokus kepada penangkapan penjahat, sedangkan anime Ryuugajou Nanana No Maizoukin fokus kepada pencarian harta karun yangjuga dapat dilakukan detektif. Hal tersebut, membuktikan bahwa genre detektif tidak hanya berkaitan tentang penangkapan penjahat. Selanjutnya, anime Meitantei Konan I Jigen no, Sniper Psycho-Pass: The Movie(Gekijouban Psycho-Pass), Ghost In The Shell, Meitantei Konan Junkoku no Naitomea, dan Bungou Stray Dogs Season 1 memiliki akhir cerita sesuai dengan arketipe yang ada yaitu penangkapan penjahat atau pengakuan kejahatan dari pelaku. Sedangkan anime Ryuugajou Nanana No Maizoukin memiliki akhir yang tidak terpecahkan dengan baik sehingga masih menimbulkan teka-teki pada penonton.

Keseluruhan anime memiliki genre utama yaitu genre detektif yang mana dalam anime tersebut memiliki data terkait klasifikasi formula pola tindakan enam fase dan empat peran berdasarkan teori Cawelti. Selain itu pada penelitian ini memperlihatkan adanya konvensi dan invensi yang terjadi pada setiap anime detektif. Konvensi dan invensi terjadi seiring dengan perkembangan minat penonton pada genre tersebut. Semakin populer suatu genre tertentu maka akan selalu ada bentuk konvensi dan invensi sebagai pengembangan dari bentuk formula dan arketipe. Dari pengembangan tersebut 
maka akan memunculkan turunan-turunan dari genre yang sebelumnya. Jika formula dan arketipe yang baru disukai oleh penonton sebagai penikmat seni maka formula dan arketipe tersebut dapat menjadi genre baru.

\section{Daftar Pustaka}

Adi, Ida Rochani. 2011. Fiksi Populer:Teoridan Metode Kajian. Yogyakarta: Pustaka Belajar.

Cawelti, John G. 1976. Adventure, Mystery, and Romance. Chicago: The University of Chicago Press.

Creswell, J. W. 2010. Research design pendekatan kualitatif, kuantitatif, dan mixed. Yogyakarta: Pustaka Pelajar.

Faruk, H.T. 2012. Metode Penelitian Sastra: Sebuah Penjelajahan Awal. Pustaka Pelajar.

Liswana, Nurul Handayani. 2016. Analisis Formula Film Aku No Kyouten Karya Takashi Miike. Universitas Jenderal Soedirman.

Mahsun. 2005. Metode Penelitian Bahasa. Jakarta: PT Raja Grafindo Persada.

Nurgiyantoro, B. 2004. Sastra Anak: Persoalan Genre. Yogyakarta : Gadjah Mada University Press.

Poitras, G. 2001. Anime essentials: Every thing a fan needs to know. Berkeley, CA: Stone Bridge Press.

Sudaryanto. 2015. Metode dan Aneka Teknik Analisis Bahasa. Yogyakarta: Duta Wacana University Press.

Sudjiman, Panuti. 1984. Kamus Istilah Sastra. Jakarta: Gramedia.

Sugiyono, 2011. Metode Penelitian Kuantitatif Kualitatif dan R\&D. Bandung: Alfabeta.

Teeuw, A. 1988. Sastra dan Ilmu Sastra. Jakarta : Pustaka Jaya.

Wellek, R., \& Warren, A. 1995. Teori Kesusastraan: Diindonesiakan oleh Melani Budianta. Penerbit PT Gramedia Pustaka Utama. 